\title{
Peningkatan Pengetahuan Orang Tua Tentang Lingkungan Bermain Yang Sehat Di Tk Aisyiyah Bustanul Athfal Kelurahan Mamajang Dalam Kecamatan Mamajang Kota Makassar
}

\author{
Iwan Sain $^{1 *}$, Junaidi ${ }^{2}$, Nuraeni Jalil ${ }^{3}$, Yosephin Sari ${ }^{4}$ \\ 1*. Poltekkes Kemenkes Makassar, Jl. Monumen Emmy Saelan III Tidung, Kota Makassar, Indonesia 90222 \\ 2. Poltekkes Kemenkes Makassar, Jl. Monumen Emmy Saelan III Tidung, Kota Makassar, Indonesia 90222 \\ 3. Poltekkes Kemenkes Makassar, Jl. Monumen Emmy Saelan III Tidung, Kota Makassar, Indonesia 90222 \\ 4. Poltekkes Kemenkes Makassar, Jl. Monumen Emmy Saelan III Tidung, Kota Makassar, Indonesia 90222 \\ *e-mail : iwansain@gmail.com
}

\begin{abstract}
Abstrak
Tujuan pengabdian masyarakat ini adalah untuk menambah pengetahuan orangtua tentang lingkungan bermain yang sehat bagi anak baik di dalam maupun diluar rumah. Metode dan alat yang digunakan dalam kegiatan ini adalah pemberian edukasi berupa ceramah dan simulasi terkait : Lingkungan bermain anak yang sehat, pertolongan pertama pada kecelakaan, simulasi menata lingkungan bermain yang sehat bagi anak dan melakukan pretest dan post test sebelum dan setelah kegiatan. Media yang digunakan adalah modul pembelajaran. Kegiatan ini dilaksanakan pada tanggal 1 dan 2 Nopember 2018 bertempat di TK Aisyiah Bustanul Athfal Kelurahan Mamajang Kecamatan Mamajang Dalam Kota Makassar. Alat yang digunakan 1). Seperangkat alat / media penyuluhan seperti gambar, pengeras suara. 2). Modul Panduan Lingkungan bermain yang sehat bagi Anak. Pihak-pihak yang terlibat dalam kegiatan ini adalah Kepala sekolah dan Orang tua murid TK Aisyiah Bustanul Athfal Jln. Tupai No. 35 Makassar. Hasil kegiatan adalah terjadinya peningkatan pengetahun peserta yang dapat dilihat dari hasil Evaluasi Pre dan Post Test yang menunjukan bahwa terjadi peningkatan nilai hasil tes berkisar antara 40-55 point dari nilai sebelumnya. Hasil evaluasi tingkat kemanfaatan kegiatan dengan menggunakan skala likert didapatkan seluruh peserta pelatihan (100\%) menilai bahwa pelatihan sangat bermanfaat. Kesimpulan kegatan ini adalah terjadinya peningkatan pengetahuan pada kelompok orangtua yang mengikuti pelatihan tentang lingkungan bermain yang sehat bagi anak.
\end{abstract}

Kata Kunci : Lingkungan Bermain Anak

\section{Pendahuluan}

Anak adalah merupakan bagian dari warga kabupaten/kota. Prediksi WHO (World Health Organitation) mencatat, bahwa diperkirakan hingga tahun 2025, separuh dari 6,5 milyar jumlah penduduk dunia akan hidup di daerah perkotaan. Menurut Lynch Kota yang ideal adalah kota yang menyediakan berbagai fasilitas penghuninya agar tidak 'sakit' termasuk yang dibutuhkan oleh anak-anak. Untuk itu kehadiran anak dalam suatu kota, perlu dipertimbangkan keberadaannya.

Namun kondisi yang terjadi di negara yang sedang berkembang, pembangunan di daerah pedesaan dan di daerah perkotaan mengalami perbedaan yang sangat mencolok. Kebanyakan pembangunan masih terpusat di perkotaan sehingga meningkatkan angka urbanisasi.

Keadaan seperti ini memberikan dampak negatif terhadap lingkungan bermain anak seperti yang terjadi di negara-negara berkembang dalam proses perkembangan kotanya. Lingkungan bermain yang baik dan memadai adalah penting sebagai bagian dari lingkungan pendukung dalam tumbuh kembang anak yang sehat. Bermain merupakan sarana bagi anak-anak untuk belajar mengenal lingkungan kehidupan sekitarnya. Pada saat bermain, anak-anak mencobakan gagasan-gagasan mereka, bertanya serta mempertanyakan berbagai persoalan, dan memperoleh jawaban atas persoalan-persoalan mereka. Bermain tidak sekedar hanya bermain-main saja. Bermain memberikan kesempatan pada anak untuk mengembangkan kemampuan motorik halus, motorik kasar, sosial dan komunikasi bahasa mereka melalui interaksinya dalam bermain dengan teman bermainnya. Secara fisik, bermain memberikan peluang bagi anak untuk mengembangkan kemampuan motoriknya. Dalam bermain, anak juga belajar berinteraksi secara sosial, berlatih untuk saling berbagi dengan orang lain, meningkatkan tolerasi sosial, dan belajar berperan aktif untuk memberikan kontribusi sosial bagi kelompoknya (KLA, 2017).

Setiap tahun, hampir 1 juta anak meninggal karena kecelakaan dan lebih dari puluhan juta anak-anak lainnya memerlukan perawatan rumah sakit karena mengalami luka berat dan hamper separuhnya disebabkan karena anak diluar pengawasan orang tua saat bermain di dalam dan diluar rumah. Di antara yang luka berat banyak yang menjadi cacat permanen dan mendapat gangguan fungsi otak. Di Indonesia angka kematian anak akibat kecelakaan, keracunan 
dan trauma tercatat 7,3\% pada 1992 dan merupakan salah satu dari lima penyebab kematian anak tertinggi. Kecelakaan darat pada anak - sesuai data Riset Kesehatan Dasar (Riskesdas) Departemen Kesehatan tahun 2007 - sebesar 19,2\% sedangkan kecelakaan lalu lintas jalan raya yang terjadi pada anak sesuai data dari Markas Besar Kepolisian Republik Indonesia (Mabes POLRI) tahun 2009 adalah sebesar 8.601 anak (8,8\%). Kecelakaan menjadi penyebab utama kematian dan kecacatan pada anak-anak. Kecelakaan yang biasa terjadi adalah jatuh, terbakar, tenggelam dan kecelakaan lalu lintas akibat melakukan aktivitas bermain yang tidak diawasi oleh orang tua atau pengasuh. Beberapa kasus kecelakaan di Indonesia juga diakibatkan bom atau bahan peledak yang banyak tersisa dari perang dunia dan perang kemerdekaan yang dimainkan oleh anak-anak. Umumnya kecelakaan terjadi di dekat rumah tempat anak bermain. Hampir semuanya dapat dicegah dan dapat diatasi jika orang tua tahu apa yang harus mereka lakukan untuk mencegah kecelakaan dan jika terjadi kecelakaan (Kemenkes RI, 2010).

Kecelakaan dapat juga terjadi akibat konstruksi rumah yang tidak memenuhi syarat kesehatan seperti lantai yang licin (Kementerian PU dan PR, 2016)

Anak bermain, karena menyenangkan. Bermain juga merupakan kunci untuk perkembangan belajar mereka. Bermain, baik secara terstruktur mapun tidak terstruktur menjadi landasan bagi perkembangan anak untuk pembelajaran masa mendatang ataupun keterampilan hidupnya. Dengan bermain, anak akan memperoleh : 1) Pengembangan pengetahuan, pengalaman, peminatan dan rasa percaya diri mereka. 2) Pengalaman belajar dengan mencoba berbagai hal, membandingkan hasil, mengajukan pertanyaan dan menghadapi tantangan. 3) Pengembangan keterampilan bahasa, berpikir, merencanakan, mengorganisasikan, dan mengambil keputusan. Stimulasi, bermain dan diikutsertakan dalam permainan dengan anak lain dan orang dewasa, merupakan hal penting bagi anak cacat dan sakit kronis, seperti anak penderita HIV. Ketika orang tua dan pengasuh bicara serta bergaul dengan anak dalam bahasa ibu, hal itu akan membantu anak untuk mengembangkan kemampuan berpikir dan mengekspressikan diri mereka sendiri. Anak belajar bahasa sangat cepat dan mudah melalui pendengaran dan menyanyikan beberapa lagu, mendengarkan atau dibacakan cerita, mengulangi ritme dan memainkan beberapa permainan.

Anak perempuan dan laki-laki memiliki kesempatan yang sama untuk bermain dan bergaul dengan seluruh keluarga, termasuk saudara sekandung, kakek, nenek, dan dalam berbagai kegiatan diluar rumah. Bermain dan bergaul dengan ibu dan ayah, sangat membantu mempererat ikatan antara anak dengan kedua orang tua. Anggota keluarga dan pengasuh dapat membantu anak belajar dengan cara memberikan tugas ringan dengan petunjuk jelas, menyediakan berbagai benda untuk bermain dan menyarankan kegiatan baru. Berikan kesempatan yang luas kepada anak untuk bermain, jangan didominasi oleh orang tua atau dewasa. Semua anak memerlukan variasi dari bahan mainan sederhana yang cocok dengan tahap perkembangan dan pembelajaran. Air, pasir, kardus, blok bangunan kayu, dan jambangan serta penutupnya merupakan mainan yang tidak kalah bagusnya dengan mainan yang dibeli dari toko mainan. Orang tua dan pengasuh harus sabar jika anak memaksa untuk melakukan sesuatu tanpa mau dibantu. Anak belajar dengan mencoba, sampai mereka berhasil. Selama anak dilindungi dari bahaya, mencoba untuk melakukan sesuatu yang baru dan sulit merupakan hal positif untuk perkembangan anak. Anak selalu tetap berubah dan mengembangkan kemampuan baru. Pengasuh harus mengamati bebagai perubahan ini dan mengikuti arah anak. Ketika anak tumbuh makin besar, mereka memerlukan kesempatan untuk belajar dan bergaul dengan anak lainnya yang sebaya. Kelompok kegiatan belajar, yang diselenggarakan oleh pengasuh terlatih atau guru di rumah atau taman kanak-kanak adalah penting untuk membantu anak siap masuk sekolah (Kemenkes RI, 2010).

Dunia anak adalah dunia bermain. Melalui kegiatan bermain semua aspek perkembangan anak ditumbuhkan sehingga anak - anak menjadi lebih sehat sekaligus cerdas. Aspek perkembangan anak dapat ditumbuhkan secara optimal dan maksimal melalui kegiatan bermain. Mengajak anak - anak bermain pada usia prasekolah telah terbukti mampu meningkatkan perkembangan mental dan kecerdasan anak. ( Adriana, 2011 ).

Berdasarkan hal tersebut pengetahuan orang tua dalam menata lingkungan bermain anak sangatlah diperlukan agar anak tetap sehat, terhindar dari penyakit dan mengalami pertumbuhan serta perkembangan secara optimal (KLA, 2017).

\section{Metode}

Metode dan materi yang disajikan dalam kegiatan ini adalah pelatihan berupa ceramah dan simulasi mengenai lingkungan bermain anak yang sehat, pertolongan pertama pada kecelakaan, melakukan simulasi menata lingkungan bermain yang sehat bagi anak dan Tanya jawab. Sebelum dan setelah kegiatan dilakukan tes pre dan pos tes.

A. Pengenalan dan persiapan

Adapun jadwal kegiatan disusun sebagai berikut :

1. Persiapan

Persiapan yang dilakukan meliputi kegiatan-kegiatan sebagai berikut :

a. Mengajukan surat ijin kegiatan

b. Merancang metode kegiatan

c. Persiapan materi dan media penyuluhan

d. Penyebaran undangan kepada calon peserta 


\section{Pelaksanaan}

Kegiatan pengabdian kepada masyarakat ini dilaksanakan selama dua hari yaitu pada tanggal 01 Nopember 2018 melakukan pelatihan dan tanggal 02 Nopember 2018 melakukan simulasi dengan menggunakan modul yang telah disiapkan. Peserta pelatihan sebanyak 10 orang dengan rincian sebagai berikuit :

Table 1. Daftar Nama Peserta

\begin{tabular}{|l|l|c|l|c|}
\hline No. & Responden & Umur & Pendidikan & Alamat \\
\hline 1 & Ny. R & 28 & SMA & Kel. Mamajang Dalam \\
\hline 2 & Ny. IN & 33 & SMA & Kel. Mamajang Dalam \\
\hline 3 & Ny. A & 29 & SMA & Kel. Mamajang Dalam \\
\hline 4 & Ny. M & 28 & SMA & Kel. Mamajang Dalam \\
\hline 5 & Ny. L & 37 & SMA & Kel. Mamajang Dalam \\
\hline 6 & Ny. N & 33 & SMA & Kel. Mamajang Dalam \\
\hline 7 & Ny. RR & 32 & SMA & Kel. Mamajang Dalam \\
\hline 8 & Ny. S & 30 & SMA & Kel. Mamajang Dalam \\
\hline 9 & Ny. I & 31 & SMA & Kel. Mamajang Dalam \\
\hline 10 & Ny. D & 34 & SMA & Kel. Mamajang Dalam \\
\hline
\end{tabular}

Pelaksanaan kegiatan bertempat di TK Aisyiah Bustanul Athfal Kelurahan Mamajang Dalam Kecamatan Mamajang Kota Makassar. Materi yang diberikan dalam pelatihan ini adalah Lingkungan bermain yang sehat bagi anak baik di dalam maupun di luar rumah.

Tabel 2. Materi Pelatihan

\begin{tabular}{|c|c|c|c|c|}
\hline Materi & Metode & $\begin{array}{c}\text { Alat } \\
\text { Peraga }\end{array}$ & Durasi & $\begin{array}{c}\text { Waktu dan } \\
\text { Tempat }\end{array}$ \\
\hline $\begin{array}{c}\text { 1. Lingkungan } \\
\text { Bermain yang Sehat } \\
\text { 2. Pengertian } \\
\text { Lingkungan } \\
\text { Bermain yang Sehat } \\
\text { 3enata Lingkngan } \\
\text { Bermain yang Sehat } \\
\text { 4. Lingkungan } \\
\text { Bermain Anak }\end{array}$ & $\begin{array}{c}\text { Ceramah, } \\
\text { Tanya } \\
\text { jawab }\end{array}$ & $\begin{array}{c}\text { gambar, } \\
\text { pengeras } \\
\text { suara }\end{array}$ & 50 menit & $01-11-2018$ \\
\hline $\begin{array}{c}\text { Menata Lingkngan } \\
\text { Bermain yang Sehat }\end{array}$ & Praktikum & Modul & 50 menit & $02-11-2018$ \\
\hline
\end{tabular}

Tabel 3. Hasil Evaluasi Pre dan Pos Tes

\begin{tabular}{|c|c|c|c|c|c|}
\hline \multirow[b]{2}{*}{ No } & \multirow{2}{*}{$\begin{array}{c}\text { Nama } \\
\text { Peserta } \\
\text { Pelatihan }\end{array}$} & \multicolumn{2}{|c|}{ Nilai } & \multirow[b]{2}{*}{$\begin{array}{c}\text { Selisih } \\
\text { nilai }\end{array}$} & \multirow[b]{2}{*}{ Predikat } \\
\hline & & $\begin{array}{l}\text { Pre } \\
\text { Test }\end{array}$ & $\begin{array}{l}\text { Post } \\
\text { Test }\end{array}$ & & \\
\hline 1. & Ny. R & 45 & 95 & 50 & Sangat Memuaskan \\
\hline 2. & Ny. IN & 40 & 90 & 50 & Sangat Memuaskan \\
\hline 3. & Ny. A & 50 & 95 & 45 & Sangat Memuaskan \\
\hline 4. & Ny. M & 40 & 90 & 50 & Sangat Memuaskan \\
\hline 5. & Ny. L & 45 & 95 & 50 & Sangat Memuaskan \\
\hline 6. & Ny. N & 50 & 95 & 45 & Sangat Memuaskan \\
\hline 7. & Ny. RR & 40 & 90 & 50 & Sangat Memuaskan \\
\hline 8. & Ny. S & 45 & 95 & 50 & Sangat Memuaskan \\
\hline 9 & Ny. I & 45 & 95 & 50 & Sangat Memuaskan \\
\hline 10 & Ny. D & 50 & 95 & 45 & Sangat Memuaskan \\
\hline
\end{tabular}

\section{Hasil}

A. Karakteristik Peserta

Peserta pelatihan adalah kelompok sasaran orang tua siswa TK Aisyiah Bustanul Athfal Kelurahan Mamajang Dalam Kecamatan Mamajang Kota Makassar.

Jumlah peserta sebanyak 10 orang dengan latar belakang pendidikan seluruhnya SMA sebaran usia berkisar antara 28 hungga 37 tahun.

B. Respon peserta

Untuk mengetahui manfaat kegiatan makan dilakukan evaluasi setelah selesainya kegiatan. Evaluasi kegiatan bertujuan untuk mengetahui tentang seberapa besar manfaat yang dirasakan oleh peserta pelatihan. Instrument yang digunakan adalah analisis tingkat kemanfaatan dengan menggunakan skala likert yang terdiri 10 pertanyaan dengan 5 point jawaban yang setiap point memiliki nilai mulai nilai terendah (0) dan nilai tertinggi (5). 
Berdasarkan hasil evaluasi Tingkat Kemanfaatan pelatihan didapatkan hasil seluruh peserta pelatihan (100\%) menilai bahwa kegiatan pelatihan yang diikuti adalah sangat bermanfaat.

C. Dampak

Dampak positif dari terselenggaranya program pengabdian masyarakat ini, yakni bertambahnya pengetahuan kelompok sasaran orang tua siswa dalam hal lingkungan bermain anak yang sehat baik di dalam maupun di luar rumah.

Hasil evaluasi tingkat pemahaman peserta pelatihan setelah dilakukan pre dan pos tes maka didapatkan selisih nilai antara pre dan pos tes adalah berkisar antara 45 sampai dengan 55 point. Hal ini menunjukkan bahwa peserta pelatihan telah meningkat pemahamannya sebesar 45 sampai dengan $55 \%$ dari pemahaman sebelumnya tentang lingkungan bermain anak yang sehat.

\section{Kesimpulan}

Berdasarkan hasil kegiatan dan pembahasan pada kegiatan pengabdian masyarakat ini, maka dapat disimpulkan bahwa terjadinya peningkatan pengetahuan pada kelompok orangtua yang mengikuti pelatihan tentang lingkungan bermain yang sehat.

\section{Rekomendasi}

A. Laporan ini sebagai sumber referensi bagi pengabdi yang berminat melakukan pengabdian kepada masyarakat dengan topik yang sama

B. Kepada pihak terkait laporan ini sebagai masukan dalam pengambilan kebijakan dibidang kesehatan

\section{Referensi}

Kemenkes RI, 2010. Penuntun Hidup Sehat Edisi keempat. www.factsforlifeglobal.org [on line] diakses tanggal 30 Juli 2019.

Kementerian PU dan PR, 2016. Panduan Pembangunan Perumahan dan Pemukiman Pedesaan Dasar-dasar Rumah Sehat. Litbang.pu.org.id [on line] diakses tanggal 30 Juli 2019.

KLA, 2017. Kondisi Lingkungan Bermain Anak. [on line] diakses tanggal 30 Juli 2019. 